\title{
Worker's material and mental life in sustainable development of industrial zones
}

\author{
Ai Nhan Nguyen ${ }^{1, *}$ and Xuan Thi Tran ${ }^{1}$ \\ ${ }^{1}$ Graduate Academy of Social Sciences, 477, Nguyen Trai str., Hanoi, 10000, Vietnam
}

\begin{abstract}
Since the implementation of the market economy, innovation and international integration, with the correct guidelines and policies of the Communist Party and the State, Vietnam has rapidly developed industrial parks, attracting a large number of foreign and domestic enterprises came to operate in industrial zones. Having a large number of employees, enterprises operating in industrial zones must pay attention to working conditions and other issues for workers. One of the most important issues of concern is the material and mental life of workers. A sufficient material life when ones' needs for food, accommodation, clothes, etc. are satisfied allows workers to survive and regenerate their energy for work. A healthy mental life ensures brings positive mood, motivation, attitude and effective working behaviors. Inadequate material and mental life reduces workers' productivity and thus influences firms' growth. Ensuring material and mental life for workers in industrial zones is a prerequisite in boosting productivity and achieving sustainable development. This study use survey and interview data to examine the quality of material and mental life of workers in industrial zones in Vietnam. Low income was the main hindrance to a sufficient material life and a rich mental life of workers. In addition, low quality of meal and working conditions had significant impacts to their health. The results were discussed in relation to previous studies on the life of workers in industrial parks.
\end{abstract}

\section{Introduction}

Upon end of June 2019, our country had 326 industrial zones with total natural area reaching approximately 95.5 thousand hectares, in which agricultural land was 65.6 thousand hectares, accounting for $68.7 \%$. In 326 established industrial zones, there were 251 industrial zones which came into operation with total natural land of 66.2 hectares and 75 industrial zones were in process of compensation, clearance and construction with total area around 29.3 thousand hectares. Full fill rate of industrial zones were operating to be nearly. Estimated that in six first months of 2019, industrial zones, economical zones in our country attract about 340 foreign investment projects with new registered capital reaching 8,7 billions USD, enhancing total project with foreign investment to be about 8.900 projects and registered capital reaching 186 billion USD (Industrial Zone Department, 2019).

\footnotetext{
*Corresponding author: jennynguyengass@gmail.com
} 
The industrial parks have not only brought an important source of funding for the national income of the country, but also contributed significantly to creating jobs and improving intellectual standards for workers. Until May 2006, industrial zones in Vietnam have attracted 1.5 millions of workers, 864,000 of which are direct workers (Pham Manh Ha, 2017). In Ho Chi Minh City alone, industrial parks and export processing zones attracted 274,662 people, of which $71 \%$ are employed by foreign-invested enterprises (Pham Manh Ha, 2017).

In recent years, many problems have arisen among workers in industrial zones. According to add extraction, nearly $70 \%$ of workers in industrial parks are migrants. They have to live in difficult conditions. They have to rent houses around the industrial areas to live with very temporary living conditions. Very few businesses build houses or residences for workers. Currently, only $6.5-15 \%$ of the workers in industrial zones live in houses built by businesses ( add extraction). Some firms fire workers illegally for arbitrary reasons, waive insurance payment for employees or are slow to increase workers' salary in accordance with market fluctuations. Many enterprises pay little attention to working conditions; as a result, workers have to work in polluted environment which negatively affects their health.

Workers are the driving force of the industry. Ensuring their material and mental needs is a way to achieve sustainable growth of an enterprise and sustainable development of industrial zones. In this article, we examined the material and mental life of workers in foreign-invested enterprises in industrial parks. 1 Introduction

Since the implementation of the market economy, innovation and international integration, with the correct guidelines and policies of the Communist Party and the State, Vietnam has rapidly developed industrial parks, attracting a large number of foreign and domestic enterprises came to operate in industrial zones. Upon end of June 2019, our country had 326 industrial zones with total natural area reaching approximately 95.5 thousand hectares, in which agricultural land was 65.6 thousand hectares, accounting for $68.7 \%$. In 326 established industrial zones, there were 251 industrial zones which came into operation with total natural land of 66.2 hectares and 75 industrial zones were in process of compensation, clearance and construction with total area around 29.3 thousand hectares. Full fill rate of industrial zones were operating to be nearly. Estimated that in six first months of 2019, industrial zones, economical zones in our country attract about 340 foreign investment projects with new registered capital reaching 8,7 billions USD, enhancing total project with foreign investment to be about 8.900 projects and registered capital reaching 186 billion USD (Industrial Zone Department, 2019).

The industrial parks have not only brought an important source of funding for the national income of the country, but also contributed significantly to creating jobs and improving intellectual standards for workers. Until May 2006, industrial zones in Vietnam have attracted 1.5 millions of workers, 864,000 of which are direct workers (Pham Manh Ha, 2017). In Ho Chi Minh City alone, industrial parks and export processing zones attracted 274,662 people, of which $71 \%$ are employed by foreign-invested enterprises (Pham Manh Ha, 2017).

Having a large number of employees, enterprises operating in industrial zones must pay attention to working conditions and other issues for workers. One of the most important issues of concern is the material and mental life of workers. A sufficient material life when ones' needs for food, accommodation, clothes, etc. are satisfied allows workers to survive and regenerate their energy for work. A healthy mental life ensures brings positive mood, motivation, attitude and effective working behaviors. Inadequate material and mental life reduces workers' productivity and thus influences firms' growth. In recent years, many problems have arisen among workers in industrial zones. According to add extraction, nearly $70 \%$ of workers in industrial parks are migrants. They have to live in difficult 
conditions. They have to rent houses around the industrial areas to live with very temporary living conditions. Very few businesses build houses or residences for workers. Currently, only $6.5-15 \%$ of the workers in industrial zones live in houses built by businesses ( add extraction). Some firms fire workers illegally for arbitrary reasons, waive insurance payment for employees or are slow to increase workers' salary in accordance with market fluctuations. Many enterprises pay little attention to working conditions; as a result, workers have to work in polluted environment which negatively affects their health.

Workers are the driving force of the industry. Ensuring their material and mental needs is a way to achieve sustainable growth of an enterprise and sustainable development of industrial zones. In this article, we examined the material and mental life of workers in foreign-invested enterprises in industrial parks.

\section{Materials and methods}

This paper used data collected by the government-funded project "Labor disputes and strikes in joint-venture companies and foreign-invested companies in Vietnam" by $\mathrm{Vu}$ Dung in 2016. The project surveyed 5,862 people with questionnaires and interviewed 100 people from 69 foreign-invested enterprises in 6 industrial parks of Ho Chi Minh City, Dong Nai Province and Binh Duong Province, Vietnam. We extract data on material and mental life of workers for analysis in the current paper. Material life was measured by monthly income, monthly expenses, meal quality, working conditions, working hours and accommodation. Mental life was measured by entertainment activities and employeremployee relationship.

\section{Results and discussion}

\subsection{Material life of workers}

One of the most important issues for employees is wages and bonuses. Because this is a decisive factor in meeting the essential material needs of workers, such as food, accommodation, clothes and traveling. We found that workers' salary is higher than the national minimum wage, but lower than workers' monthly spending. The average monthly income was VND 2 million, including VND 1.2 to 1.5 million for basic salary and an additional VND 0.5-0.8 million for overtime (the lowest is VND 970,000, the highest is VND 8-10 million for intermediate management officials).

Salary is decided based on employees' educational background. Image 1 is the salary announcement board of Cerie Vietnam Garment Company. Minimum salary for skilled workers is VND 1,170,000 per month while minimum salary for unskilled workers is VND $1,100,000$ per month. 


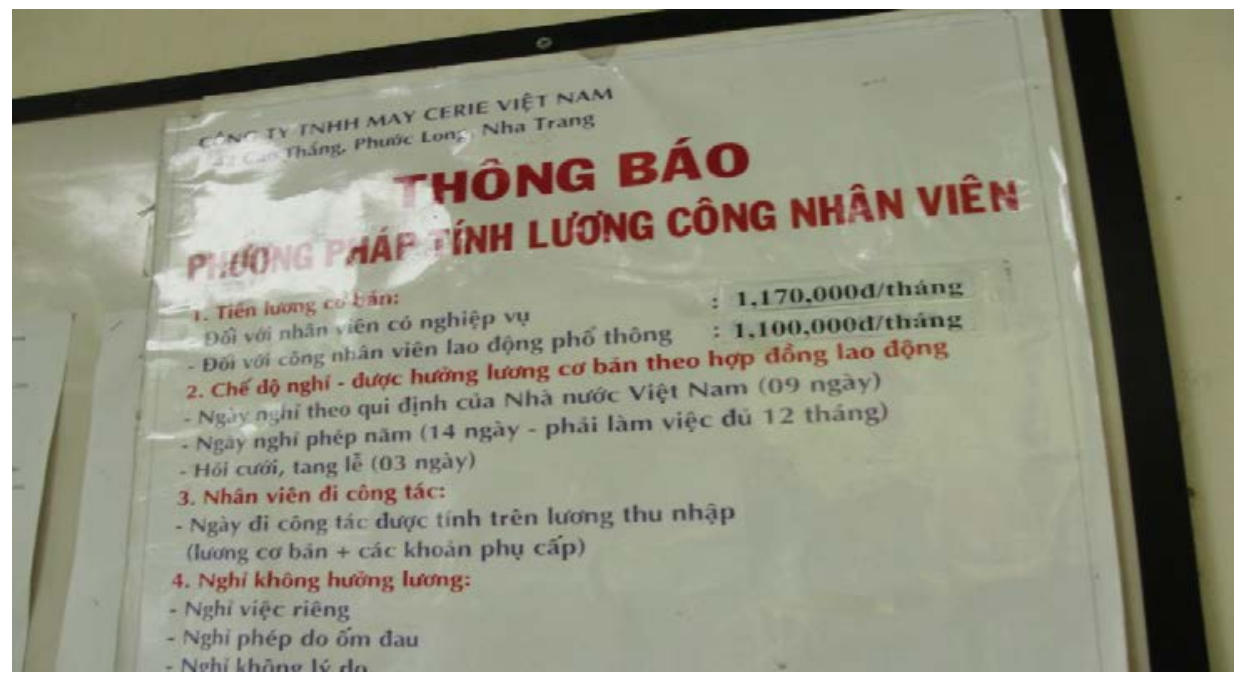

Fig. 1. Salary of workers at Cerie Vietnam Garment Company.

This finding is in line with previous studies. Dang Ngoc Tung (2008) found that in 2007 , only $20.2 \%$ of workers in industrial parks had an income of VND 800,000 $1,000,000$ per month (equivalent to USD $40-50$ ), $23.8 \%$ of workers had an income of over VND 1.5 million per month (equivalent to 70 USD). Thus, $56 \%$ of workers earn less than VND 1 million per month (USD 45).

We asked workers if their income was enough to meet to their monthly expenses. Table 1 showed workers' response.

Table 1. The monthly expenditure of the employee based on salary.

\begin{tabular}{|c|c|}
\hline Monthly expenses & Rate (\%) \\
\hline Enough & 31.5 \\
\hline Not enough & 68.5 \\
\hline
\end{tabular}

The above survey data shows that the majority of employees cannot afford monthly expenses. Only over a third of workers can pay their monthly expenses. The rate of workers who could make ends meet in this study was higher than the rate found by a previous study by the Institute of Workers and Trade Unions (2010). Survey results of the Institute of Workers and Trade Unions in 2007 found that $42.8 \%$ of workers said their monthly income did not guarantee the normal life of themselves and their families.

Their monthly income was mostly spent on food and rent (see Table 2). With a salary of VND 1,000,000 per month, a worker has to pay at least VND 950,000 per month for food and rent and is left with VND 50,000 (= 2.5 USD) for other needs. With this amount of money, they cannot afford to send their children to school or go for entertainment activities. $71.7 \%$ of workers said that they did not have monthly savings.

Table 2. Average monthly expenditure of workers by salary.

\begin{tabular}{|c|c|c|}
\hline Monthly spending & Amount of money (VND) & Rate of respondents \% \\
\hline \multirow{3}{*}{ Rent money } & $<350,000$ & 32.7 \\
\cline { 2 - 3 } & 350,000 & 45.5 \\
\cline { 2 - 3 } & $>350,000$ & 21.8 \\
\hline \multirow{3}{*}{ Money for meals } & $<600,000$ & 37.0 \\
\cline { 2 - 3 } & $600,000-1,000,000$ & 37.0 \\
\cline { 2 - 3 } & $>1,000,000$ & 26.0 \\
\hline
\end{tabular}


Their situation was demonstrated in their interview responses:

"With the current income status, workers do not have enough money for basic needs and they will feel stressful when working" (female worker, 19 years old, educational level 9/12, working at the company for 7 months).

"The key issue is that the income is too low while expenses for many things are escalating. Trade unions have also actively contributed their voices to employers but the reply from employers is slow and inadequate" (Male union worker, 33 years old, working at the enterprise for 15 years).

"At present, the market prices are increasing while workers' income is low and workers are facing difficulties in their lives" (Female workers, 27 years old, secondary education, working for the company for 6 years).

We observed the meals of workers in boarding houses provided by the companies. Their meal was quite simple with two or three dishes (fish/meat, vegetables and soup). Through in-depth interviews, workers expressed their concern with diet sufficiency. Most of them were young adults working in high intensity and required more food to maintain and recreate working energy.

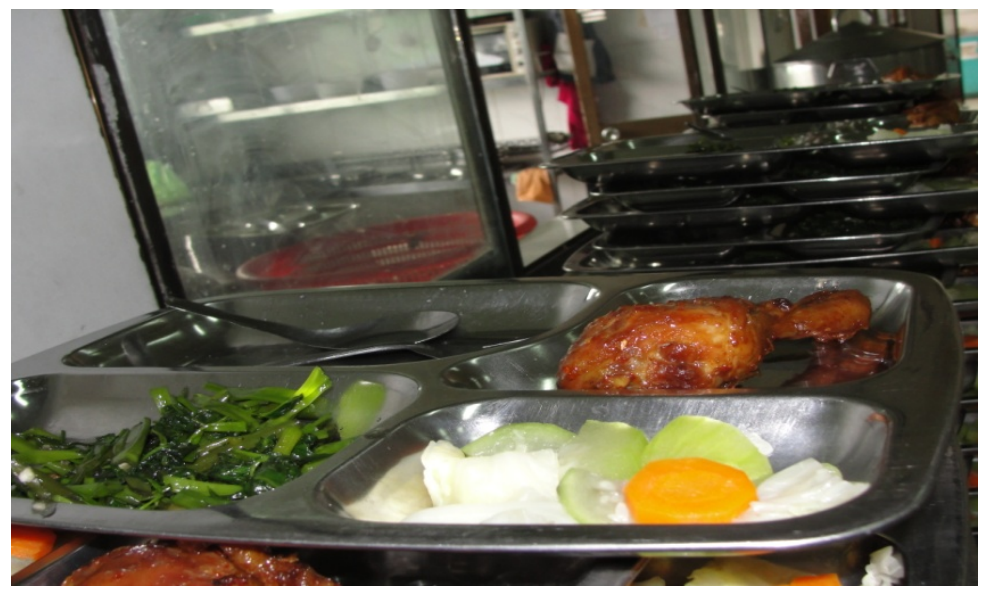

Fig. 2. Workers' meal.

Working conditions are very important not only for the productivity and quality of work of workers, but also for the health of workers. The survey results showed that $87.5 \%$ of workers claimed that "working conditions are not guaranteed".

In most of the surveyed enterprises, workers suffered from low hygienic working conditions. In seafood processing companies, the air is polluted by the waste of fish and shrimp. In toy and textile manufacturing companies, the fabric dust also affects the health of workers. In many factories of some companies, the temperature is quite high due to insufficient air conditioners and fans. Noise level in mechanical companies is high, exceeding the prescribed threshold.

This is in line with previous studies: $40 \%$ of workers said the working conditions are poor; $24 \%$ said the working conditions are normal (Institute of Workers and Trade Unions, 2010); $22.1 \%$ said they are not equipped with labor protection equipment; $36 \%$ said they have good working conditions (Nguyen Van Nhat, 2010).

Labor accidents are also a matter of concern for businesses. According to statistics of the Bureau of Occupational Safety, each year there are about 4600 occupational accidents, killing over 500 people, injuring about 5000 people (Dang Ngoc Tung, 2008).

$84.7 \%$ of workers surveyed said that their working time was longer than that agreed in the labor contract signed with the business owner. We observed that most companies 
require workers to work overtime to complete products under the signed contracts with customers. Working time of workers usually lasted up to 10 hours per day. However, their wages were not commensurate with the energy that workers spent.

Accommodation of workers was in low quality. Usually 2 - 3 workers live in a rented room of $10-12 \mathrm{~m}^{2}$. The furniture in the room includes a bed, an electric fan, a gas cooker, saucepans, dishes. Few rooms have televisions, desks, radios or disc players.

In industrial zones in this survey, only $2-7 \%$ of workers were allowed to rent houses built by the state or enterprises; the remaining $93-98 \%$ of workers have to find their own accommodation. In Ho Chi Minh City, $65 \%$ of workers have to rent accommodation; in Binh Duong and Can Tho, 70\% of workers have to rent accommodation. Because of low income, workers have to rent temporary housing, which is usually cramped, hot, unhygienic and unsafe. Each room of 7-10m2 without private toilet and bathroom was shared by 3-4 people (Nguyen Van Nhat, 2010).

\subsection{Mental life of workers}

Mental life is also very important for workers. While a sufficient material life ensures survival, a healthy mental life brings good mood, work more effectively, and ensure good health. However, as discussed above, their material life was inadequate. Over and above spending on food and accommodation, workers' monthly expenditure also includes clothes, appliances, wedding gifts, birthdays, movies, music, sightseeing, medicine, etc. Two-thirds of workers surveyed did not have any saving, putting them in a difficult situation if they are sick or when they have to visit their hometown during Tet holiday. Lack of saving also means no monthly allowance to send back to their family members in hometown - an expected act in migrant workers.

Low income leads to a poor mental life. When asked if they had money to spend on going to the cinema/theatre, most workers reported no (see Table 3 ). This rate accounted for more than $2 / 3$ of the respondents. The number of people having money to go to the cinemas and music shows accounted for nearly one third of the workers. Most of workers in the latter group were young people who were in love. Through in-depth interviews, we learned that people who had their own families and children had a much harder life.

Table 3. Workers' spending on going to the cinema or theater.

\begin{tabular}{|l|c|}
\hline Do you spend money on going to the cinema or theater? & Rate (\%) \\
\hline Yes, I have enough money for it & 21.9 \\
\hline No, I can't afford it & 78.1 \\
\hline
\end{tabular}

The Institute of Workers and Trade Unions (2010) found that $41.6 \%$ of workers sometimes watched television, 40.3\% sometimes read newspapers. According to a sociological survey of workers in Binh Duong, $71.8 \%$ of workers never went to the cinema; $88.2 \%$ did not go to music shows; $84.7 \%$ did not go to sports; $95.3 \%$ never went to recreational, recreational, and cultural clubs; $89 \%$ entertained themselves with television (Nguyen Van Nhat, 2010). Pham Manh Ha (2007) studied the mental life of workers in industrial zones and found that workers, after working hours at enterprises, are less involved in cultural and sports activities. They spend most of their time on taking rest, playing games or gambling, meeting friends or lovers, experiencing a life together before marriage, living together. The main reason was workers have to pay rent and could not afford cultural and sports activities. For those participating in social activities organized by enterprises, it is mainly due to mandatory participation (55.5\%).

Another aspect of the mental life of workers in industrial zones is the relationship between leaders and workers. Phan Mai Huong (2008) found that conflicts between employers and workers frequently occurred in foreign-invested enterprises. Usual conflict 
with $3,1 \%$; Sometime conflict with $31,9 \%$; rare conflict with $42,9 \%$ and never conflict with $22,1 \%$.

Regarding causes of conflict, leaders' unfair evaluation accounted for $23.1 \%$; contradictions in relation accounted for $22.3 \%$; contradictions on leadership accounted for $28.9 \%$ (Phan Mai Huong, 2008). When the leaders fail to guarantee transparency and fairness in treating and evaluating workers, it will create a negative mood among workers. Workers tend to be discouraged, dissatisfied, and less active, fail to ensure work quality, and can make defective products.

Research results at 69 foreign-invested enterprises by Vu Dung et al (2016) found that $56.2 \%$ of workers said their business owners violated the dignity policy; $53.2 \%$ of business owners did not understand Vietnam's customs and practices. Respect for workers' dignity is a factor that constitutes the positive working attitude of workers. This is because the need for self-actualization is a mental need of each person and a high level of need in Maslow's hierarchy of needs. Why do employers fail to respect and even humiliate their workers? This needs to be seen from two sides: On the side of the manager, they think that they are the boss and have the right to criticize or insult their workers when their workers do not comply with their regulations. As for the workers, some of them still lack the industrial working style, work arbitrarily, carelessly, lack self-awareness, do not have the spirit of cooperation and sharing in working. When moving from a small-scale economy with an arbitrary, highly personal and non-disciplined working style to a market economy with an industrial and highly disciplined working style, many workers fail to adapt to. When business owners apply the vision and industrial leadership style to businesses in Vietnam where there are many workers with the background of smallholder farmers, they fail to adapt to it.

$\mathrm{Vu}$ Dung et al (2012) (need to add this document into reference) found that the majority of surveyed young workers were not satisfied with their jobs and income (61.2\%); only more than $1 / 3$ of surveyed young workers were satisfied with their jobs and income $(38.8 \%)$. As such, young workers had low satisfaction with their jobs and income. They found their work unattractive and their income insufficient. It is worth mentioning that the majority of surveyed young workers did not want to change their jobs $(63.9 \%)$ despite their dissatisfaction. This situation implies that workers had difficulty in changing jobs and low job adaptability. For young workers who were satisfied with their jobs $(38.8 \%)$, the percentage of who were extremely satisfied with their jobs accounted for a low rate $(14 \%)$ while the rest were satisfied and slightly satisfied with their jobs. The biggest reason young workers were unhappy with their jobs was low income $(65 \%)$. Some other reasons were unsuitable job and dependence on relatives (Vu Dung, 2012).

Regarding the working motivation of workers, the survey results show that the working motivation of the majority of workers was to satisfy the basic material needs of life, to ensure their living daily, while the motivation to improve professional and career levels was not high.

\section{Conclusion}

Our research found that the material and mental life of workers in foreign-invested enterprises were not guaranteed. Workers' income is too low to meet their monthly spending. The majority of workers have no saving from their income. This will be difficult for them when they are sick and when sending their children to school or visiting family can cost them a lot. Meals, working conditions and accommodation conditions of workers in many enterprises have not been guaranteed well. Most of the employees have to rent houses, their living conditions are inadequate, and they have to live at cramped and unsafe places. Many workers are not satisfied with their jobs. Their life motives are not positive. 
The mental life of the surveyed workers is deprived. Most of workers do not attend entertain activities such as music shows, cinemas, sports or arts activities. The relationship between business owners and workers in many businesses is poor. Cultural differences have led to conflicts between foreign business owners and local workers.

Restrictions on material and mental life of workers in industrial zones have been negatively affecting the business activities of enterprises, thereby negatively affecting the development of industrial zones. It should be noted that workers are a decisive factor in the development of industrial zones.

\section{References}

1. Ministry of Planning and Investment: 20 years of foreign investment - Looking back and moving forward from 1987 to 2007 (Knowledge Publisher, 2008)

2. Nguyen Huu Dung, Strikes in Vietnam: Situation and solutions. Research report (2010)

3. $\mathrm{Vu}$ Dung, Labor disputes and strikes in joint-venture companies and foreign-invested companies in Vietnam. Executive report of government-funded research project (2016)

4. Le Thanh Ha, Electronic Communist Review (2008)

5. Phan Mai Huong, Basic psychological issues of workers in state-owned enterprises, foreign-invested enterprises, and private enterprises. Executive report of ministryfunded research project (2008)

6. Pham Manh Ha, Active participation in social activities of workers in industrial parks in Vietnam today. Research report (2017)

7. Basco reports establishment and development of industrial zones and processing zones in six months of 2019. Online report (Industrial zone department, Ministry of Investment and Planning, 2019)

8. Le Thi Minh Loan, Nguyen Van Luot, Activeness of workers in Vietnamese businesses today (Hanoi National University Publisher, 2017)

9. Nguyen Van Nhat, Building and developing Vietnamese workers' culture in the process of renovation and international integration. Executive report of government-funded research project (2010)

10. Dang Ngoc Tung, Electronic Communist Review (2008)

11. Vietnam class of workers - Current status and development trends (Institute of Workers and Trade Unions, Labor Publishing House, 2010)

12. Tran Van Than, Journal of Social Sciences 4 (2010)

13. Pham Thi Kim Thanh, Communist Review 14 (2008)

14. Nguyen Huu Dung, Communist Review 14 (2008)

15. Le Thanh Ha, Communist Review 14 (2008)

16. Tran Ngoc Thanh, Communist Review 45 (2010) 